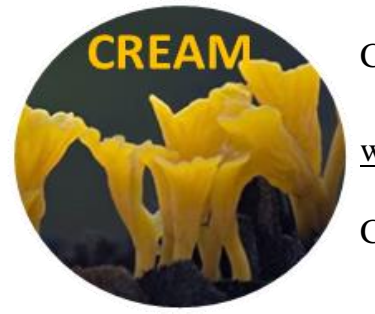

Current Research in Environmental \& Applied Mycology 4 (1): 126-135 (2014) ISSN 2229-2225

www.creamjournal.org

Article

CREAM

Copyright @ 2014

Doi 10.5943/cream/4/1/11

Online Edition

\title{
Three new records of Poroid Aphyllophorales to Indian fungal flora from Pune district
}

\section{Ranadive KR*}

Department of Botany, Waghire College, Saswad, Tal-Purandar, Maharashtra, India

Ranadive KR 2014 - Three new records of Poroid Aphyllophorales to Indian fungal flora from Pune district. Current Research in Environmental \& Applied Mycology 4 (1): 126-135, Doi $10.5943 /$ cream/4/1/11

\begin{abstract}
Pune is an important district of Maharashtra. Western Ghats of Pune districts is very much rich in the fungal flora of fleshy as well as wood rotting fungi. Three records namely Phellinus arctostaphyli (Long) Niemelä., Phellinus sanfordii (C.G. Lloyd) Ryvarden \& Podoscypha petaloides (Berk.) Boidin are the valuable additions to the total count of Aphyllophoraceous fungal diversity from India for the first time.
\end{abstract}

Key words - Basidiomycetes - fungi - semi-evergreen forest - Western Ghats

\section{Introduction}

The major importance of the species of Aphyllophorales as a whole is their saprobic activities as decomposers, particularly in the degradation of cellulose and lignin. Many Aphyllophorales species decay wood of trees that are already dead, but some particular species in the families Polyporaceae, Hymenochaetaceae, Stereaceae and Hericiaceae, are known to enter the wounds in living trees and to make their way to the heartwood. These species make the way by a series of physical and chemical changes that overcome the natural defenses of the tree. (Alexopoulos et al.2002). A total of more than 190 genera of 52 families and total 1175 species of from poroid and non-poroid Aphyllophorales fungi were reported from Indian literature till date. (Ranadive 2013) Three records namely Phellinus arctostaphyli (Long) Niemelä, Phellinus sanfordii (C.G. Lloyd) Ryvarden \& Podoscypha petaloides (Berk.) Boidin (Table 2) are the valuable additions to the total count of Aphyllophoraceous fungal diversity from India for the first time. (Ranadive 2012)

\section{Pune District}

Pune, an important district of Maharashtra is located between $17^{\circ} 52^{\prime}$ to $19^{\circ} 23^{\prime}$ North and $73^{\circ} 20^{\prime}$ to $75^{\circ} 10^{\prime}$ East and extends over an area of 15,640 sq. kms. It has a near triangular shape with its base coinciding with the continental divide, which marks the boundary between the plateu on the East and the Konkan to the West. (Fig. 2) It extends South-South-Eastwards over a distance of approximately $212 \mathrm{kms}$. Along the Sahyadri ranges, it has a North South width of about $150 \mathrm{kms}$. Pune District is in the Western region in Maharashtra in India. It is bounded by Thane District to the North-West, Raigad District to the West, Satara District to the South, Solapur District to the SouthEast, and Ahmednagar District to the North and North-East. Pune district lies in the Western Ghats or Sahyadri mountain range and it extends on to the Deccan Plateau on the East. Pune stands on the 
leeward side of the Western Ghats. Pune is at an altitude of $567.842 \mathrm{~m}$. (Anonymus 1976). The whole of the forest area in the Pune district falls under "reserved" forests category. Some of the localities show mixed type of forests in which we could get the different patches of different types of vegetation. (Table 1, Fig. 1) As the forest type changes, the Aphyllophorales fungal flora also shows the variation in the forms. The investigation area shows following types of forests in all 15 major localities from the Western Ghats of Pune district namely Tropical stunted semi-evergreen forest, Tropical stunted semi-evergreen forests and scrubby woodlands, Tropical moist deciduous forests, Tropical moist deciduous forests and scrubby woodlands and Tropical dry deciduous forests. (Anonymous 1954, Anonymous 1976)

\section{Materials and Methods}

Collection and preservation of samples - During the collection tours the fungal material, mostly dead twigs and wood with basidiocarps were examined using a 3 fold pocket lens (15X) and kept in the zip lock polythene bags as well as some times paper bags. This method though it appears simple, needed extensive screening of maximum fallen twigs, bark and wood, dead wood, dead roots of trees as well as the infected trees and shrubs. This was done during all seasons but the collections were abundant after rainy season. The specimens were brought to the laboratory and examined under a Milhard-SBM 02 stereo-binocular to observe position of the basidiocarps, their gross morphology, shape, size colour of the basidiocarp, presence or absence of the appendages etc. All the specimens described are labeled and deposited in the Department of Botany, University of Pune, Pune411007. The collected materials were kept in brown paper folders of size $20 \times 15 \mathrm{cms}$ prepared from paper of $29 \times 33 \mathrm{cms}$ size with label (Size $16.5 \times 7.5 \mathrm{cms}$ ). The specimens were photographed with the help of Panasonic FZ-50 (Pro-SLR) camera to get the best result showing all Macromorphological details of the specimen. Selection of the quality photographs was done by checking its zooming quality.

Microscopic examinations - Free hand sections of the basidiocarp were taken carefully and primary observations were made using lacto-glycerin mounts to see the colour of basidiospores, setae and other elements of the section. Sections were also stained in cotton blue and mounted in lacto-glycerin. For microscopic examinations of the basidiocarps, the specimens are sectioned along the tubes with razor blades for noting down the shape, size and dimensions of the hyphae, spores, basidia, and various setal elements. In poroid samples, the pore mouths are mostly sterile and a fertile hymenium is found a certain distance beyond the pore mouths where spores and possibly cystidia may be observed. A small context of pileal cover maybe mounted in the same preparation. The sections mounted in $5 \% \mathrm{KOH}$, can easily be squashed with a gentle tap on the coverslip and it facilitates the recording of hyphal morphology and dimensions. The spore measurements were taken from thin sections or hymenial squashes and should mostly based on the observations on spores not yet detached from their basidia. Basidiocarps and hyphae were also stained with Melzer's reagent (IKI). If they are yellow to nearly colourless they are said to be inamyloid or IKI -ve. The reaction is said to be amyloid if they turn grey or blue and dextrinoid if becomes reddish brown. Microscopic details of various representative areas of the basidiocarp, hyphal system and spores were studied as suggested by Teixeira (1962 b). Camera lucida sketches were also made for all materials with prism type camera lucida. Measurements of the basidia, cystidia, setae, spores were made by ocular of ERMA INC, made in Japan and objective micrometer of ERMA TOKYO company and eyepiece micrometer under 10X, 45X, and 100X objectives. For fructification, measurements were taken 5-10 times and average values were recorded. Identification was done by using standard literature.

\section{Observations \& Results}

During field and literature surveys, a rich mycobiota was observed in the vegetation of India. The heavy rainfall and high humidity favours the growth of Aphyllophoraceous fungi. The present work materially adds to our knowledge of Poroid and Non-Poroid Aphyllophorales from all over India. A total of more than 190 genera of 52 families and total 1175 species of from poroid and non- poroid Aphyllophorales fungi were reported from Indian literature till 2012.(Ranadive 2013) In the present study a total of 20 species of Aphyllophorales ( 8 families and 14 genera) from the 10 respective hosts were identified out of 126 collected 
Table 1 Forest Types in Western Ghats of Pune District. (Anonymous 1954, Anonymous 1976)

\begin{tabular}{ll}
\hline \multicolumn{1}{c}{ Type of Forest } & Percentage \\
\hline Tropical stunted semi-evergreen forest & $40 \%$ \\
Tropical stunted semi-evergreen forests and scrubby woodlands & $40 \%$ \\
Tropical moist deciduous forests & $6.66 \%$ \\
Tropical moist deciduous forests and scrubby woodlands & $6.66 \%$ \\
Tropical dry deciduous forests & $6.66 \%$ \\
\hline
\end{tabular}

\section{Forest Types in Western Ghats of Pune District}

\footnotetext{
- 1 Tropical stunted semi-evergreen forest

- 2 Tropical stunted semi-evergreen forests \& scrubby woodlands

3 Tropical moist deciduous forests

4 Tropical moist deciduous forests \& scrubby woodlands

5 Tropical dry deciduous forests
}

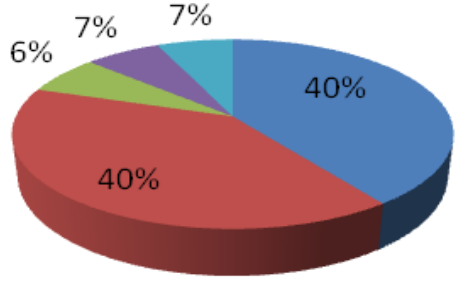

Fig. 1 - Forest types in Western Ghats of Pune District (Anonymous 1954, Anonymous 1976)

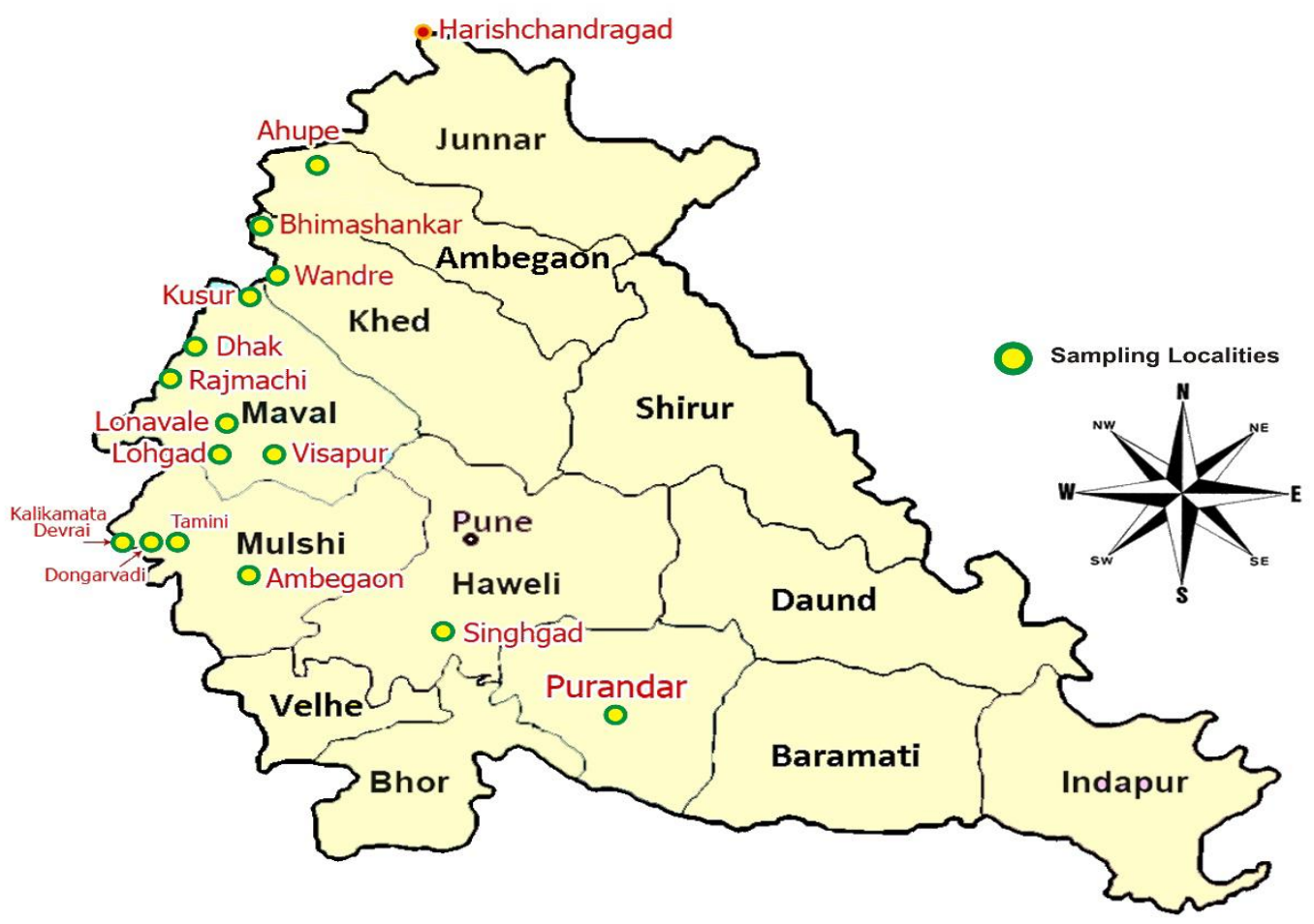

Fig. 2 - Localities of Western Ghats of Pune District 
specimens from 15 different localities throughout the Western Ghats of Pune districts, Maharashtra State.(Ranadive 2012) Western Ghats of Pune district shows three new locality records of the species for India for the first time namely Phellinus arctostaphyli (Long) Niemelä, Phellinus sanfordii (C.G. Lloyd) Ryvarden \& Podoscypha petaloides (Berk.) Boidin.

Phellinus Quel. Elench. Fung. p. 172, 1886.

The genus is wide spread in distribution with 427 known species from world and 96 from India. Basidiocarp pileate to resupinate, perennial, rarely annual, pileus dark brown to black in species with a crust, more rarely pale ochraceous, hirsute to glabrous, often sulcate now and then radially cracked in older basidiocarps, pores variable, but mostly small, tubes usually stratified, context thin and dense.

\section{Key to Phellinus species}

1 Pileus 8 to $10 \mathrm{~cm}$ long and wide and 3.5 to $4 \mathrm{~cm}$ thick at the base, woody hard; pileus tomentose, rusty brown in narrow sulcate zones, in older specimens becomes glabrous grey to black, spores 2.5$4 \times 2-3 \mu \mathrm{m}$ long, pore surface rusty to snuff brown, pores round, small, 6-8 per $\mathrm{mm}$

Phellinus sanfordii

2 Pileus 1-9 $\mathrm{cm}$ wide and $1-3.5 \mathrm{~cm}$ thick; upper surface quickly becoming glabrous and crustose, grayish, sulcate, becoming blackened and rimose with age, basidiospores ovoid, flattened on one side, hyaline, smooth, with slightly thickened walls, cyanophilous, $4-5 \times 2-3.5 \mu \mathrm{m}$. pores circular, 4 6 per $\mathrm{mm}$

Phellinus arctostaphyli

Phellinus arctostaphyli (Long) Niemelä. Ann. Bot. Fenn. 12:120. 1975.

Figs 3-A \& 4-1

Basidiocarps perennial, sessile, applanate to ungulate, dimidiate, $1-9 \mathrm{~cm}$ wide and $1-3.5 \mathrm{~cm}$ thick; upper surface quickly becoming glabrous and crustose, grayish, sulcate, becoming blackened and rimose with age; margin concolorous to light brown, rounded; pore surface pale grayish brown to dark rusty brown, smooth, the pores circular, 4-6 per mm, dissepiments thick, tomentose, entire; context reddish brown, azonate, fissile, firm, woody, up to $2 \mathrm{~cm}$ thick, tube layers indistinctly stratified, up to $1 \mathrm{~cm}$ thick. Contextual setae absent. Hymenial setae present $26.25 \times 10 \mu \mathrm{m}$, pointed with broad base, dark brown. Hyphae of fibrous context parallel, skeletal hyphae thick-walled, aseptate, with rare branching, 2.5-3.75 $\mu \mathrm{m}$ in diam; Hyphae of trama parallel, skeletal hyphae thickwalled, dark brown in $\mathrm{KOH}$, aseptate, with rare branching 2.5-5 $\mu \mathrm{m}$ diam; generative hyphae hyaline to pale yellow, thin-walled, with simple septa and occasional branching, 1.5-2.5 $\mu \mathrm{m}$ diam. Setal hyphae infrequent, thick-walled, $3.75 \mu \mathrm{m}$. Basidiospores ovoid, flattened on one side, hyaline, smooth, with slightly thickened walls, cyanophilous, $2.5-4 \times 2-3.5 \mu \mathrm{m}$.

Materials examined - On fallen sumps and dead branches, Ahupe (29/10/09) VKPO-265, 272, 271, On Lagerstromia sp., Unknown angiosperm, On fallen stumps, On dead standing tree, Dongarwadi (4/11/07, 7/5/07, 26/10/08) VKPO-102, 104, 105, 116, On dead angiospermic branches, Vinjai Devrai (12/11/08) VKPO-103, On fallen branches and stumps, Lohagad (18/10/08, 6/11/07) VKPO-106, 107, 111, On fallen stumps and parasitic on unknown angiosperm Lonawala (23/12/08) VKPO-109, 110, On fallen trunk of angiosperm Harishchandragad (23/3/08) VKPO-112, On unknown angiosperm as a parasite on bark, Kalkaimata Devrai (12/11/08) VKPO-114, On Terminalia sp., Lonawala-Kusoor (6/12/08) VKPO-115.

Remark - Typical white rot.

Distribution - Arizona,India.

Phellinus sanfordii (C.G. Lloyd) Ryvarden 1972 Norw. J. Bot. 19 (1972) 235; Ryvarden and Johansen(1980) 212.

Figs 3-B \& 4-2

Basidiocarps perennial, pileate, single to imbricate, semicircular, applanate to convex, 8 to 10 $\mathrm{cm}$ long and wide and 3.5 to $4 \mathrm{~cm}$ thick at the base, woody hard; pileus tomentose, rusty brown in narrow sulcate zones, in older specimens becomes glabrous grey to black, in zones from the base, 
Table 2 List of new Aphyllophorales records from India.

\begin{tabular}{|c|c|c|c|c|}
\hline Family & $\begin{array}{l}\text { Name of the } \\
\text { fungus }\end{array}$ & Host & $\begin{array}{c}\text { Type of } \\
\text { basidiocarp }\end{array}$ & Locality \\
\hline Hyemnochaetaceae & $\begin{array}{l}\text { Phellinus } \\
\text { arctostaphyli } \\
\text { (Long) Niemelä. }\end{array}$ & $\begin{array}{l}\text { On wooden stumps of } \\
\text { Lagerstromia } \\
\text { Terminalia sp. }\end{array}$ & $\begin{array}{l}\text { Applanate to } \\
\text { Ungulate }\end{array}$ & $\begin{array}{l}\text { Ahupe, Dongarwadi- } \\
\text { Vinjai Devrai Lohagad, } \\
\text { Lonawala, } \\
\text { Harishchandragad, } \\
\text { Kalkaimata Devrai } \\
\text { Lonawala-Kusoor }\end{array}$ \\
\hline & $\begin{array}{l}\text { Phellinus } \\
\text { sanfordii (C.G. } \\
\text { Lloyd) Ryvarden }\end{array}$ & $\begin{array}{l}\text { On dead angiospermic } \\
\text { wood }\end{array}$ & $\begin{array}{l}\text { Pileate Single to } \\
\text { imbricate }\end{array}$ & Lonawala \\
\hline Meruliaceae & $\begin{array}{l}\text { Podoscypha } \\
\text { petaloides (Berk.) } \\
\text { Boidin }\end{array}$ & $\begin{array}{l}\text { On Fallen sticks of Ficus } \\
\text { sp., }\end{array}$ & Spathulate & $\begin{array}{l}\text { Lonawala-Dhak Bhairi, } \\
\text { Dhak Lohagad and } \\
\text { Ahupe }\end{array}$ \\
\hline
\end{tabular}

margin fairly acute; pore surface rusty to snuff brown, pores round, small, 6-8 per mm, tubes indistinctly stratified, dark cinnamon to pale rusty brown, up to $1 \mathrm{~cm}$ long in each layer; context dark cinnamon, hard, up to $5 \mathrm{~mm}$ thick, separated from the tomentum by a black line. Hyphal system dimitic; generative hyphae simple-septate, hyaline, thin-walled, 1.5-2.5 $\mu \mathrm{m}$; skeletal hyphae dominating, yellow to pale rusty brown, 3.75-6.25 $\mu \mathrm{m}$, rarely branched. Hymenial setae abundant, mostly ventricose but a few also acuminate, dark brown, straight or slightly allantoid thick walled, 12.50-26.25 × 6-10 $\mu \mathrm{m}$. Basidia not seen. Basidiospores broadly ellipsoid, pale yellow, 2.5-5 $\times$ $2.5-3 \mu \mathrm{m}$.

Materials examined - On dead angiospermic wood, Lonawala (23/12/8) VKPO- 85, 83, 81.

Distribution - Sri Lanka, Pakistan India, and Japan.

Remark - The species is closely related to P. extensus and chiefly separated by its larger setae which are less ventricose than those of $P$. extensus.

Podoscypha Pat., Essai Tax. Hyménomyc. (Lons-le-Saunier): 70, 1900.

The genus is wide spread in distribution with 84 known species from world but no any report till date from India. Podoscypha is mainly characterized by the stipitate and flabellate basidiome, the dimitic hyphal system and the presence of gloeocystidia.

Podoscypha petaloides (Berk.) Boidin 1959

Figs 3-C \& 4-3

Basidiocarp 2-6 $\mathrm{cm}$ high and 1-2 $\mathrm{cm}$ wide. The basidiocarps are spatulate, although the edges of the pilei frequently curl inward and fuse to form pseudoinfundibuliform fructifications. The basidiocarps are usually gregarious but discrete. Pileus when fresh varying from light brown to pinkish-brown after drying becomes chestnut-brown and ornamented with darker concentric zones. Hymenial surface of dried specimens either ochraceous- or greyish buff or concolourous with the pileus. Stipe short and rudimentary. Hyphal structure dimitic, consisting of generative and skeletal hyphae. The freely branched generative hyphae, $2-5 \mu \mathrm{m}$ in diam., are thin-walled, hyaline and bear clamp-connexions at the septa. The skeletal hyphae, 2.5 to $4.5 \mu \mathrm{m}$ in diam. are thick-walled and unbranched. However, there are subcylindric pilocystidia $12.50 \mu \mathrm{m}$, on the surface of the cap which have a rather superficial origin. Hymenial cystidia are absent. Gloeocystidia abundant as elongated, thin-walled organs with highly refractive contents $40 \times 8 \mu \mathrm{m}$. These bodies are basically subcylindric, swollen base and narrow gradually toward the obtuse apex. They have the potential of unlimited growth and many traverse the entire width of the thickened hymenium; some cease to grow and become buried but their place is taken by others which arise at almost any level. Basidia 4spored, and clavate, $18 \times 9 \mu \mathrm{m}$. Spores $2.75-3.75 \times 1.5-2.5 \mu \mathrm{m}$, thin-walled, hyaline, monoguttulate, varying in shape from ovate to elliptical. 


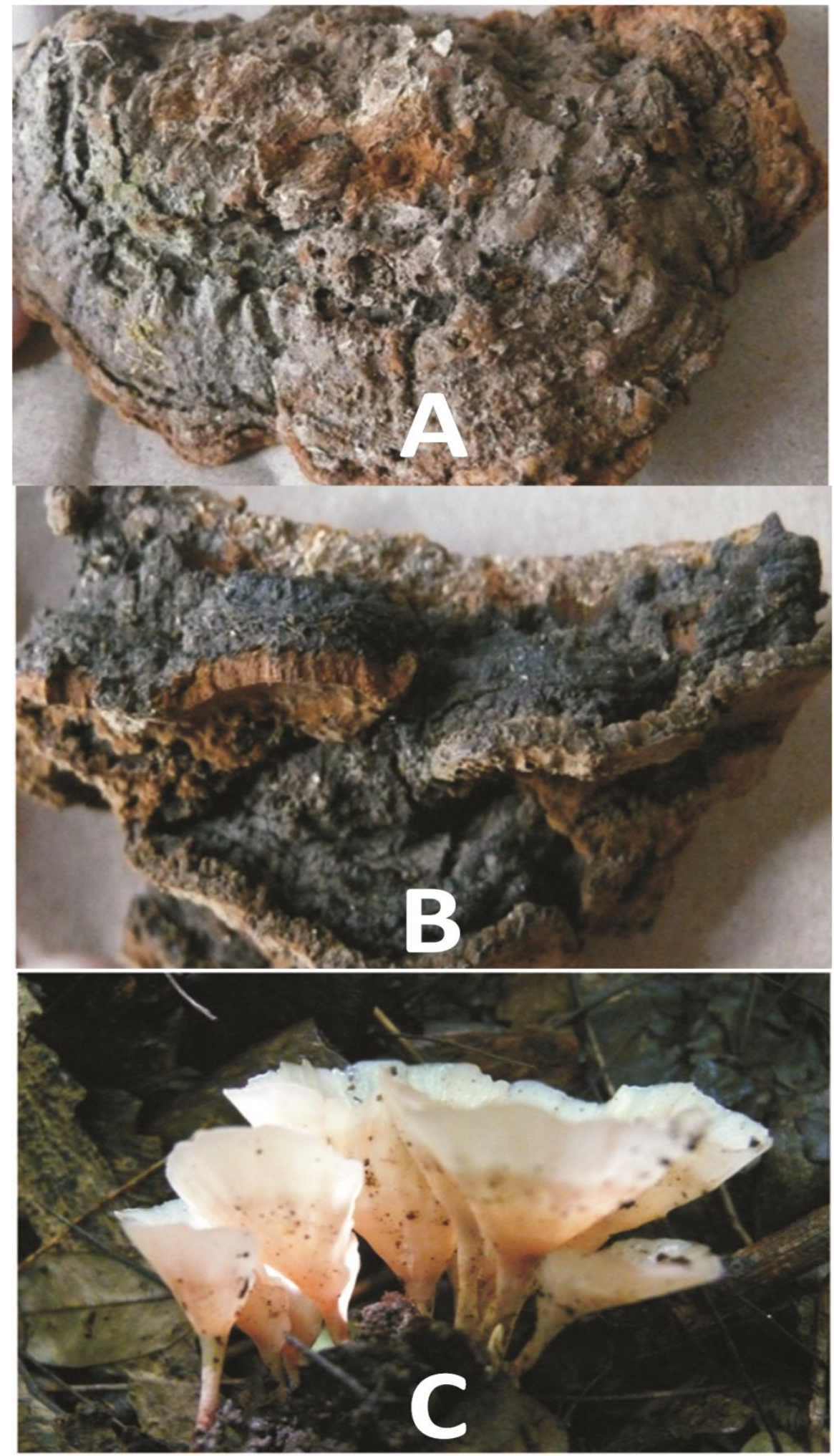

Figs 3 - A. Phellinus arctostaphyli (Long) Niemelä., B. Phellinus sanfordii (C.G. Lloyd) Ryvarden. C. Podoscypha petaloides (Berk.) Boidin.

Material examined - On dead wood of Ficus sp., Lonawala-Dhak Bhairi Dhak (2/11/08) VKPO-239, On dead stumps Lohagad (6/11/07) VKPO-264, On fallen branches of angiosperms, Ahupe (29/10/09) VKPO-289.

Distribution - America, Pacific Islands.

Remarks - The basidiocarp is very thin than that of Microporus and it is fleshy when fresh. 


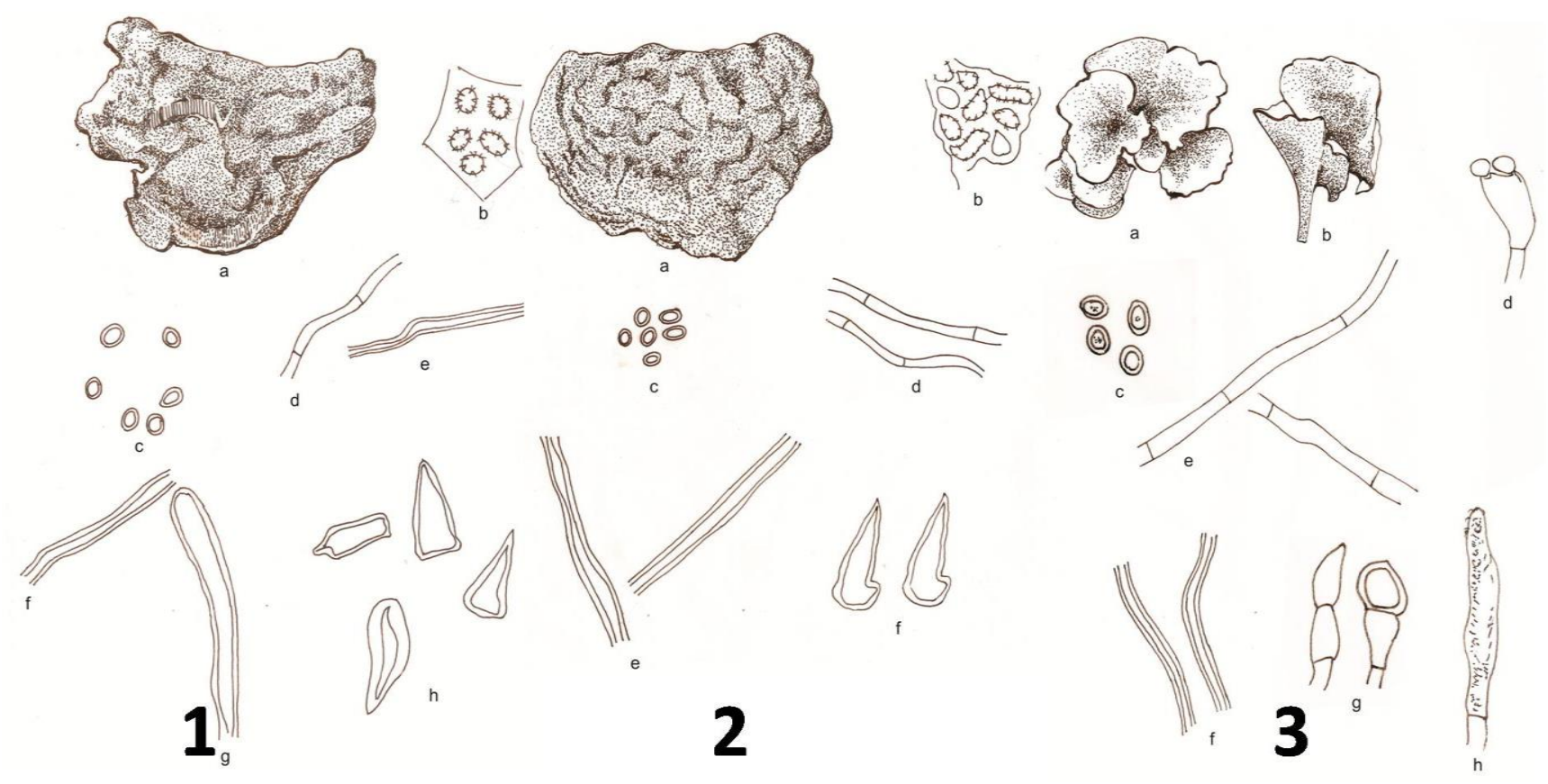

Figs 4 - 1. Phellinus arctostaphyli (Long) Niemelä. a. Habit, b. Pore shape, c. Basidiospores (2.5-4 $\times 2-3.5 \mu \mathrm{m})$, d. Generative hyphae $(1.5-2.5 \mu \mathrm{m})$, e. Skeletal hyphae $(2.5-5 \mu \mathrm{m}), \mathrm{f}$. Hymenial setae $(26.25 \times 10 \mu \mathrm{m})$., 2. Phellinus sanfordii (C.G. Lloyd) Ryvarden a. Habit, b. Pore shape, c. Basidiospores $(2.5-5 \times 2.5-3 \mu \mathrm{m})$, d. Generative hypha $(1.5-2.5 \mu \mathrm{m})$, e., f. and g. Skeletal hyphae $(3.75-6.25 \mu \mathrm{m})$, f. Setae $(12.50-26.25 \times 6-10 \mu \mathrm{m})$. \& 3. Podoscypha petaloides (Berk.) Boidin a. and b. Habit, c. Basidiospores $(2.75-3.75 \times 1.5-2.5 \mu \mathrm{m})$, d. Basidium $(18 \times 9 \mu \mathrm{m})$, e. Generative hyphae $(2-5 \mu \mathrm{m})$, f. Skeletal hyphae $(2.5$ to $4.5 \mu \mathrm{m}) \mathrm{g}$. Pilocystidia $(12.50 \mu \mathrm{m})$, h. Gloeocystidium $(40 \times 8 \mu \mathrm{m})$.

\section{Acknowledgement}

I am very much thankful to all scientists and contributors for contributing towards the Aphyllophorales Flora of India. I can't forget the help and guidance extended by well known Indian Mycologists Prof. (Dr.) Anjali Roy, Dr. Ashit Baren De and Prof. P.N. Ganesh, regarding basic Aphyllophorales taxonomy. I can't express my feelings in words about the help extended by Prof. Leif Ryvarden, Prof. P. Kirk, Dr. D. Minter, in taxonomic literature and database help. I am very much thankful to Hon. Sandip Kadam, Secretary of PDEA, Pune and Dr. R. M. Misal, Principal for their constant inspiration for this work. I especially wish to express my appreciation to Yogesh Ambikar for his tremendous help during collection of samples. My sincere thanks are due to Mr. Janrao and Mr. Rahul Kale (ARI Pune, Library) who helped me a lot during the survey of literature. I am very much fortunate to have had understanding and ever helping circle of friends like Prof. Shriniwas Ipalpalli, Prof. Neeta Jagtap, Dr.Shekhar Bhosale and Dr. Gauri Bapat and parents for their constant support and inspiration.

\section{References}

Ainsworth GC, Sparrow FK, Sussaman AS. 1973 - The Fungi Vol. IVB. Academic Press N. York and London.

Alexopoulos CJ, Mims CW, Blackwell IM. 2002 - Introductory Mycology. John Wiley and Sons, Inc., New York.

Anonymus 1976 - Geology of the Pune District. Maharashtra. Geological Survey of India. $12^{\text {th }}$ Anniversary Celebration.

Anonymus 1954 - Gazetteer of Bombay State, District Series- Volume XX, Poona District, Government Central Place. 
Bapat G, Vaidya J, Garad S, Bhosale S, Ranadive K, Belsare M. 2011 - Screening of four species of Phellinus and optimizing Phellinus badius for biomass and exo-polysaccharide production. Int. Journ. of Applied. Biol. 2 (2), 14-17.

Belsare MH, Bapat GS, Ranadive KR, Vaidya JG, Deokule SS. 2010 - In - vitro susceptibility testing of some Phellinus species against Acinetobacter baumannii from Maharashtra India. Journal of Medicinal Plants Research. 4(13), 1335-1338.

Belsare MH, Ranadive KR, Bapat GS, Garad S, Deokule SS, Vaidya JG. 2013 - Screening of mushroom Phellinus switeniae (Murr.) S. Herrera and Bondart against clinical isolates of Acinetobacter baumannii Bouvet \& Grimont. Elixir Appl. Botany 54, 12398-12399.

Bhosale S, Ranadive K, Bapat G, Garad S, Deshpande G, Vaidya J. 2010 - Taxonomy and Diversity of Ganoderma from the Western parts of Maharashtra (India). Mycosphere 1(3), 249-262.

Bose SR. 1944 - Importance of Anatomy in Systematics of Polyporaceae. J. Ind. Bot. Soc. 23,153157.

Butler EJ, Bisby GR. 1931 - The Fungi of India. The Imperial Council of Agricultural Research. India. Sci. Monogr. 1, 237. : revised by R. S. Vasudeva, Published, I. C. A. R. New Delhi, 1960.

Champion HG, Seth SK. 1968 - Revised survey of the forest types of India. Government of India publication, New Dehli.

Ganesh PN, Leelavathy KM. 1986 - New records of Phellinus from India. Current Science 55, 727728.

Gilbertson RL 1979 - The genus Phellinus (Aphyllophorales: Hymenochaetaceae) in Western North Amercia. Mycotaxon 9, 51-89.

Hakimi MH 2008 - Studies in some resupinate Aphyllophorales. Ph. D. Thesis, Department of Botany University of Pune.

Hakimi MH, Vaidya JG, Ranadive KR, Jamaluddin, Jite PK. 2013 - Resupinate Aphyllophorales of India. Scientific Publishers (India).

Harsh NSK. 1982 - Studies on wood -decaying fungi of Kumaun hills. Ph. D. Thesis, Department of Botany, Government Science College, Jabalpur.

Hennings P 1901 - Fungi Indiae Orientalis- II, O. W. Gollana 1900 Collecti. Hedwigia 40, 323-342.

Jagdale RP 1994 - Ecology of Bhimashankar Forest Western Ghats, Maharashtra state. Ph. D. thesis, Department of Botany, University of Poona, Pune.

Janardhanan KP 1966 - The Flora of Bhimashankar and surrounding areas of Khed Taluka, Poona District, Maharashtra State. Ph. D. Thesis. University of Pune.

Kirk PM et al. 2008 - Ainsworth and Bisby's Dictionary of the fungi. CAB International UK.

Larsen MJ, Cobbe-Poulle LA. 1990 - Phellinus (Hymenochaetaceae) A Survey of the world taxa. Fungiflora,Oslo.

Leelavathy KM, Ganesh PN. 2000 - Polypores of Kerala. Daya Publishing House, Delhi-110035.

Mahabale TS 1987 - Maharashtra State Gazetteers, General State Series, Botany- Part IV, Botany and Flora of Maharashtra.

Naik-Vaidya CD 1990 - Wood Rotting Fungi from Karnala and Kankeshwar Ph. D. Thesis, Department of Botany, University of Pune.

Nair NC, Danial P. 1986 - The floristic diversity of the Western Ghats and its conservation: A review. Proceedings of the Indian Academy of Sciences (Animal Science/Plant Science) Supplement. 127-163.

Nanda MK 1996 - Wood Rotting Fungi from Bhimashankar Ph. D. Thesis, Department of Botany, University of Pune.1-397.

Natrajan K, Kolandavelu K. 1985 - Resupinate Aphyllophorales from South India I. Kavaka 13 (2), 71-76.

Rabba AS 1994 - Studies in the genus Phellinus Quel. from Maharashtra. Ph. D. Thesis, University of Pune, Pune. 
Ranadive KR 2012 - Studies in Aphyllophoraceous fungi from the Western Ghats of Pune Districts, Maharashtra State. Ph. D. Thesis, University of Pune.

Ranadive KR 2013 - An overview of Aphyllophorales (wood rotting fungi) from India. Int. J. Curr. Microbiol. App. Sci. 2(12), 112-139.

Ranadive KR, Jagtap NV, Vaidya JG. 2012 - Host diversity of genus Phellinus from world.Elixir Appl. Botany 52, 11402-11408.

Ranadive KR, Belsare MH, Deokule SS, Jagtap NV, Jadhav HK, Vaidya JG. 2013 - Glimpses of antimicrobial activity of fungi from World. Journal on New Biological Reports 2(2), 142 162.

Ranadive KR, Jagtap NV. 2013 - Preliminary Checklist of fungal flora of Kas lateritic plateau and surroundings from the North Western Ghats of Maharashtra State. Elixir Appl. Botany 60 (2013), 16637-16640.

Ranadive KR, Vaidya JG, Jite PK, Ranade VD, Bhoslae SR, Rabba AS, Hakimi M, Deshpande GS, Rathod MM, Forutan A, Kaur M, Naik-Vaidya CD, Bapat GS, Lamrood P. 2011 - Checklist of Aphyllophorales from the Western Ghats of Maharashtra State, India. Mycosphere 2 (2), 91-114.

Ranadive KR, Joshi T, Khare H, Jagtap NV, Jite PK, Ranade VD, Vaidya J. 2012 - Host Distribution of Phellinus from India. Indian Journal of Forestry. 35 (1), 67-72.

Ranadive KR, Jite PK, Ranade VD, Vaidya J. 2013 - Flora of Aphyllophorales from Pune DistrictPart I. Journal on New Biological Reports 2(3), 188-227.

Rattan SS 1977 - Resupinate Aphyllophorales of North Western Himalaya. Bibliotheca Mycologica $60,1-427$.

Roy A 1971 - Anatomy of India Polyporaceae.V. Polyporus anthelminticus Berk. Visva Bharati Annals (Sc.) Part II. 14, 20-29.

Roy A, De AB. 1996 - Polyporaceae of India. International book distributor, Dehra Dun-248001, India.

Ryvarden L 1973 - New genera in the Polyporaceae. Norw. J. Bot. 20, 1-5.

Ryvarden L 1991 - Genera of Polypores. Nomenclature and taxonomy. Synopsis Fungorum 5, Fungiflora - Oslo-Norway.

Ryvarden L., Dhanda RS. 1975 - Two remarkable polypores from India. Transactions of the British Mycological Society 65, 413-417.

Ryvarden L, Johansen I. 1980 - A preliminary Polypore flora of East Africa, Fungifiora, Oslo.

Sathe AV, Rahalkar S.R. 1977 - Checklist of Polyporaceae from south West India. I. Biovigyanum 2,103-105.

Sharma JR 1995 - Hymenochaetaceae of India. Calcutta, India. Botanical Survey of India.

Sharma JR 2000 - Genera of Indian Polypores. Botanical Survey of India, Calcutta 700001.

Shetty BV, Kaveriappa KM. 1991 - The Western Ghats-need for preservation. In: Perspectives on

Dakshina Kannada and Kodagu. Maangalore University Decennial Volume. 258-272.

Sheshawat Trust. 2004 - Study of the people-forest relationship and local resource management systems in Bhimashankar area, district Pune, Maharashtra: Final report 2004. Pune.

Shetty BV, Kaveriappa KM, Bhat KG. 2002 - Plant Resources of Western Ghats and Lowlands of Dakshina Kannada and Udupi Districts. Pilikula Nisarga Dhama Society, Moodushedde, Mangalore.

Stalpers SJ 1978 - Identification of wood-inhabiting Aphyllophorales in pure culture. Studies in Mycology, 16 Central Schimmel-cultures. Baarn, 16, 1-248.

Sunarmani S, Madurajan D. 1925 - Some Polyporaceae of Madras Presidency. Madras Agricultural Department. Year Book. 1924, 69-75.

Sydow HP, Butler EJ. 1906 - Fungi Indiae orientalis Part I. Ann. Mycol. 4, 424-445.

Sydow HP, Butler EJ. 1911 - Fungi Indiae Orientalis Parts II. Ann. Mycol. 9, 372-421.

Sydow HP, Butler EJ. 1907 - Fungi Indiae Orientalis Parts. II. Ann. Mycol. 5, 485-515.

Sydow HP, Bulter EJ. 1912 - Fungi Indiae Orientalis Parts IV. Ann. Mycol. 10, 243-280. 
Sydow HP, Butler EJ. 1916 - Fungi Indiae Orientalis Parts. V. Ann. Mycol.14,177-220.

Synge H 2005 - Biodiversity Hotspots. Plant Talk.

Talbot PHB 1951 - Studies of some South African resupinate Hymenomycetes-I. Bothalia 6, 1-116.

Talbot PHB 1958 - Studies of some South African resupinate Hymenomycetes-II. Bothalia 7, 131187.

Teixeira AR 1962 b - The taxonomy of the Polyporaceae. Biol. Rev. 37, 51-81.

Thind KS 1961 - The Clavariceae of India. I.C.A.R. New Delhi.

Thind KS 1973 - The Aphyllophorales in India. Indian Phytopathology 26, 2-23.

Thind KS 1975 - Recent trends in the taxonomy of Aphyllophorales. In Advances in Mycology and Plant pathology ed. By S. P. Rayehudhuri.

Vaidya JG 1987 - Ecological characteristic of wood decay and cord forming fungi from the campus of Poona University. Poona University Press, Pune. 1-100.

Vaidya JG, Bhor GL. 1990 - Medicinally important wood Rotting Fungi with special emphasis on Phansomba. Deerghayu VI, 1-4.

Vaidya JG, Rabba AS. 1993 a - Fungi in Flok Medicine. Mycologist 7, 131-133.

Vaidya JG, Rabba AS. 1993 b - Valid names for some common Indian wood Rotting Polypores, their Synonyms and Authenticity II. Journal of the Indian Academy of wood Science 24, 3556.

Vaidya JG, Nanda MK, Rabba AS. 1991 - Community and substratum composition for wood Rotting Aphyllophorales from Bhimashankar, Western Ghats. Proceedings of the Sixth Engineering Congress on Transdisciplinary premise of Ecology and Environment, Institute of Engineers, Pune: India. 22(3), 56-70.

Vaidya JG, Rabba AS, Nanda MK. 1994 - Systematic study of the genus Phellinus from Bhimashankar forest. Biologia Indica.

www.cbs.knaw.nl - 2013

www.fungifromindia.com - 2012

www.indexfungorum.org -2011

www.mycobank.org - 2012 